\title{
Oyster Mortality Studies In Virginia .V. Epizootiology Of MSX A Protistan Pathogen Of Oysters
}

Jay D. Andrews

Virginia Institute of Marine Science

Follow this and additional works at: https://scholarworks.wm.edu/vimsarticles

Part of the Aquaculture and Fisheries Commons, and the Marine Biology Commons

\section{Recommended Citation}

Andrews, Jay D., Oyster Mortality Studies In Virginia .V. Epizootiology Of MSX A Protistan Pathogen Of Oysters (1966). Ecology, 47(1), 19-31.

$10.2307 / 1935741$

This Article is brought to you for free and open access by the Virginia Institute of Marine Science at W\&M ScholarWorks. It has been accepted for inclusion in VIMS Articles by an authorized administrator of W\&M ScholarWorks. For more information, please contact scholarworks@wm.edu. 


\title{
OYSTER MORTALITY STUDIES IN VIRGINIA \\ V. EPIZOOTIOLOGY OF MSX, A PROTISTAN PATHOGEN OF OYSTERS ${ }^{1}$
}

\author{
JAY D. ANDrews \\ Virginia Institute of Marine Science, Gloucester Point, Virginia
}

\begin{abstract}
MSX, a pathogen of oysters (Crassostrea virginica), produced a drastic epizootic in high-salinity areas of Chesapeake Bay from 1959 to 1963. The patterns of infection and mortality were determined by imports from disease-free seed-oyster areas. Winter and spring imports became infected in early summer and began dying in late summer. Late-summer imports apparently became infected promptly but infections remained subclinical until the following May. Death rates were highest during warm months but losses occurred throughout the year. MSX was assigned as the cause of a high percentage of deaths by sampling live and dead oysters.

Mortality for the first and second years after import was usually 50 to $60 \%$ annually. A fungus disease caused by Dermocystidium marinum was also prevalent in some areas.

Prevalence of MSX did not decline as oyster populations were decimated; hence nearly half of Virginia's private beds have been forced out of production.
\end{abstract}

\section{INTRODUCTION}

Outbreaks of introduced pests and diseases are rather commonplace in this era of rapid transportation by man (Elton 1958). Invasions of marine habitats appear to be less frequent than those on land but may be equally destructive. Malpeque disease of oysters (Needler and Logie 1947), wasting disease of eelgrass (Cottam and Addy 1947), and ichthyosporidiasis of herrings (Sindermann and Scattergood 1954) are well known examples of destructive marine diseases. The epizootiology of another marine organism, MSX, which destroyed much of the oyster industries in Delaware and Chesapeake Bays beginning in 1957 and 1959, respectively, is described here.

The origins of marine epizootics are usually vague. Infrequency and inconvenience of observations plus rapid distribution by currents tend to obscure marine pests and diseases until they are well established. Then it is difficult to determine whether the parasite is introduced or enzootic. Unfortunately, interpretations of data and selection of remedial measures often depend upon the position taken on this question of origin.

Diseases of marine organisms are very poorly known even for species such as oysters which have been extensively studied ecologically. Less than ten diseases with named causative organisms have been described for oysters. Judging from species whose pathology is well studied, far more can be expected. Vague syndromes and multiple names for apparently identical diseases abound in unpublished data of investigators working on oyster diseases. This is the background for the present attempt to describe the epizootiology of MSX, an undescribed pathogen of Crassostrea virginica.

\footnotetext{
${ }^{1}$ Contribution no. 185 from the Virginia Institute of Marine Science.
}

MSX was first observed in Chesapeake Bay in 1959 associated with serious mortalities of oysters in Mobjack Bay.

Seasonal patterns of infectivity and mortality derived from field studies are described in this paper. The activity of MSX in the James River seed area where ecological conditions are marginal for the pathogen has been described (Andrews 1964). The history of the epizootic and the distribution of MSX in Chesapeake Bay will be described in a paper by Andrews and Wood (in preparation).

MSX, a protistan parasite, has been tentatively associated with haplosporidians by Haskin, Stauber and Mackin (Haskin 1960) although no spore has been identified. Numerous attempts to produce experimental infections in the laboratory by direct transmission from oyster to oyster have failed. Hence, the epizootiological data are derived primarily from field studies with very limited control of environmental conditions. Identification of MSX by characteristic plasmodia has not been difficult and association of the pathogen with extensive mortalities in Chesapeake and Delaware Bays is generally accepted by investigators. No attempt will be made in this paper to describe the organism and the syndrome of disease it causes in oysters. Prevalences of MSX in oysters are based upon diagnoses of permanent stained slides which are available for future confirmation.

Data reported here were all collected at the Virginia Institute of Marine Science, although a rather free exchange of information has occurred at five annual "Mortality Conferences" which have been attended by personnel from laboratories of the middle Atlantic Coast. The Rutgers University group, headed by $\mathrm{H}$. H. Haskin, discovered MSX and has accumulated a set of data for Dela- 
ware Bay which more or less parallels the Institute's information for Chesapeake Bay.

\section{Methods}

Death rates are difficult to obtain on natural and planted oyster beds even if frequent counts are made. Short-term death rates are particularly hard to determine. At the Institute, oysters of known age and history have been grown in trays to study diseases and death rates (Andrews, Wood and Hoese 1962). The results have been confirmed and supplemented by counts on natural beds. Trays are placed directly on the beds to be monitored. The trays have legs which lift the oysters about a foot off the bottom, thereby eliminating most predator and bottom-associated losses yet providing similar water conditions for disease activity. Regular counts of live and dead oysters provide accurate death rates. For diseases such as Dermocystidium marinum, in which proximity of infected hosts induces spread (Andrews 1965), care must be exercised in managing trays of oysters and in interpreting results. The problem of accelerated disease activity from density of oysters in trays has not arisen with MSX.

Dead or dying oysters with meats (gapers) were obtained primarily from trays. It is impossible to be sure of the cause of death in a particular oyster even if a disease is diagnosed. For many oysters which died and in which the meats disappeared there was no opportunity to test for cause of death. For the purposes of this paper, it is presumed that mere presence of MSX in a gaper, in the absence of other recognizable pathogens, is sufficient evidence of cause of death (Andrews, unpublished data). It has been shown that gapers resulting from attacks of the fungus Dermocystidium nearly always exhibit infections categorized as "heavy" (Andrews and Hewatt 1957). Enough gapers were recovered and examined for disease to provide useful estimates of specific death rates (by a particular disease).

Intervals between tray examinations were usually less than a month, but death rates are expressed as percentage per month regardless of period of observation involved. Seasonal and annual mortalities were calculated using instantaneous mortality rates. Ricker's tables (1958) provide an easy method for estimating accumulative mortalities over longer periods.

The basic technique for field studies of MSX was to import disease-free stocks of oysters to epizootic areas at chosen times. All imports of tray oysters, unless otherwise specified, were made from a low-salinity bed of James River where no disease has ever been found. Oysters of approximately the same size and age were used in succes- sive years. These were 2- and 3-year-olds averaging about 2 inches in length. Smaller oysters are known to be less susceptible to MSX and Dermocystidium (Andrews, unpublished data; Andrews and Hewatt 1957). After importation, groups are referred to as in their first or second season or year of exposure.

Frequent sampling soon depletes the population of oysters in a tray and introduces bias. Hence only occasional samples of live oysters were taken to determine prevalence of MSX. All the prevalence figures given on mortality curves represent the number of MSX cases per 25 live oysters. When more frequent data on prevalence were needed, samples of live oysters were taken from beds of oysters with which the trays were associated.

Sample size for determination of disease prevalence (incidence) was usually 25 oysters. This represents a rather minimal size of sample for statistical purposes, but it is a feasible number to process and read.

For the purposes of this paper, data were selected only from tray stations and beds located in high-salinity waters (Fig. 1) where MSX has been destructively active since 1959 . This was

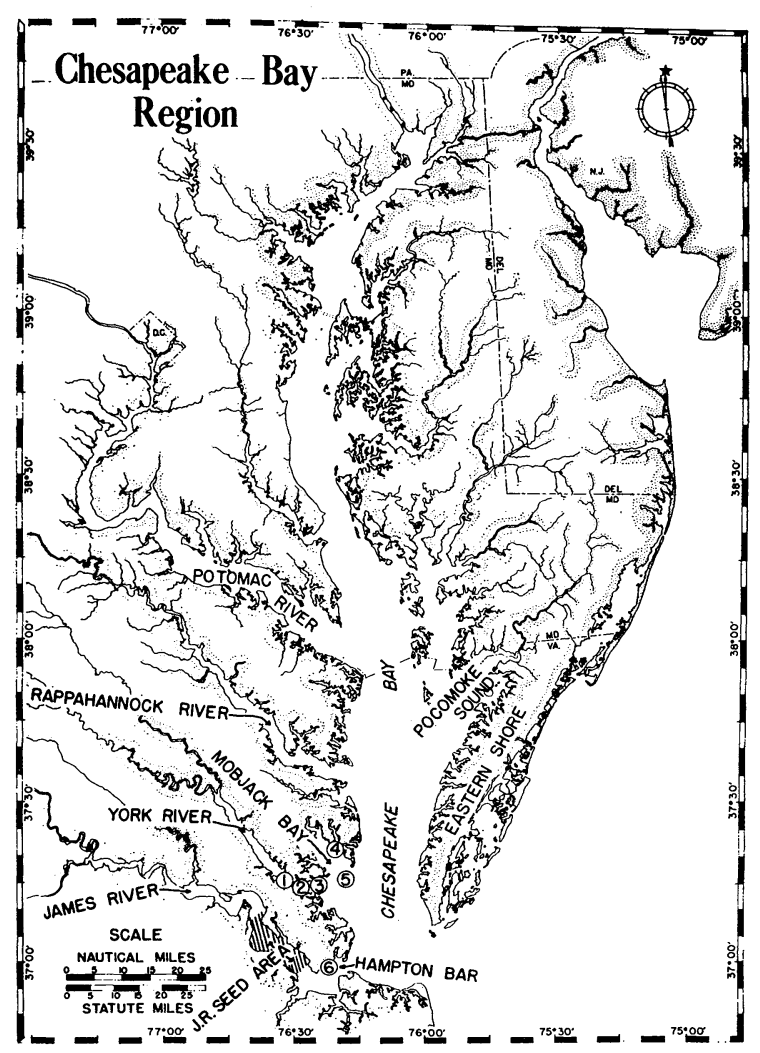

FIG. 1. Map of Chesapeake Bay showing sampling stations and beds in high-salinity waters of lower York and James rivers where MSX was fully epizootic. 
done to insure that typical incidences and death rates for highly epizootic areas were presented. These high-salinity waters range from spring salinities of about 15 to $20 \%$ o to summer salinities of about 20 to $25 \%$. A general description of hydrography in Chesapeake Bay is given by Pritchard (1952). The York River stations were located at Tillage's ground (station 1) just above the bridge, at Gloucester Point (2), at AMOCO test platform approximately 3 miles below Gloucester point near Ellen Island (3), Cuthbert and Hughes' ground (4) and on Miles' oyster ground (5) in Mobjack Bay about 2 miles southwest of New Point Comfort. The lower James River station was placed on Hampton Bar (6) between Newport News and Hampton, Virginia. All of these stations were surrounded by planted beds of oysters at the beginning of the epizootic.

\section{Results}

\section{Period of infectivity of $M S X$}

Time of initiation of infections in nature could not be determined closely because variable incubation periods are involved. After disease-free oysters were imported, intensive follow-up sampling was required to determine when cases of MSX first appeared. Imports have been classified into winter-spring and late summer-fall groups because sequences of infection and mortality followed separate patterns.

\section{Evidence from winter-spring imports}

All winter and spring imports exhibited the same patterns of infection and mortality. These patterns are exemplified by the spring imports in Figures 2, 3 and 4. MSX infections were not found in winter-spring imports until late June and did not become common until early August each year. Oysters imported in June showed the same timing of infections as others imported the previous November. Other groups, for which data are not presented, were imported in November 1959, December 1959, February 1960, March 1960 (three lots), April 1960, December 1960, and numerous lots from March to June 1961. All showed the absence of MSX infections until about August and the same timing of MSX losses in their first summer of exposure. It appears that period of infectivity did not begin until late May or early June.

\section{Evidence from under-water weighing experiments}

A closer estimate of timing and incubation period of early-summer infections was obtained by Havinga's underwater weighing technique (Andrews 1963). A group of 50 oysters was imported 6 June 1960 to trays at VIMS pier and weighed weekly. The first "sick" oyster (no weight gain) appeared on 21 July 1960 and several more were sick on 28 July 1960 . Sick oysters were killed the first week of no weight gain and tested for diseases. By 15 September 1960, 37 of the 50 oysters had been killed and all but 5 had MSX. The first oyster became sick 45 days after import and several more were sick with MSX by the 52nd day. In other groups oysters began dying within 2 or 3 weeks after sickness was indicated by lack of increase in under-water weight.

Oysters imported 13 July 1960 and 22 August 1960 were killed at intervals prior to the 45-day point in an attempt to diagnose MSX infections earlier. Strangely, MSX did not appear in these imports until May of the following year.

\section{Pattern of infectivity in late summer-fall imports}

The history of three late-summer and fall imports (trays 118, 120 and 121) is shown in Figure 3. Although many of these oysters became sick in September and October 1960, as determined by the weighing technique, occurrence of MSX was rare. Oyster tissues in stained sections did not appear disturbed. Dermocystidium was eliminated as the cause of this sickness.

In mid-May of 1961, high incidences of MSX were found in all three late-summer imports. Yet oysters imported in the winter and spring of 1960-61, of which trays 127 and 128 in Figure 3 are examples, did not develop infections until late summer as usual. It is concluded that August, September and October imports became infected before December 1960 but that these were not evident as plasmodial infections until May of 1961. It is possible that localized plasmodial infections were present but not found in sectioned material. A repetition of the long delay in appearance of infections can be seen in the late summer imports of 1962 in Figure 4. In contrast, infections did not begin to appear in spring-of-1963 imports until August.

\section{$M S X$ as an agent of death}

The causes of deaths in trays can be deduced from occurrence of pathogens in live oysters and gapers. No losses from predation, smothering and other physical causes were observed in the trays reported.

The number of MSX infections per 25 live oysters is shown for 12 lots of oysters at three York River stations in Figures 2, 3, and 4. Attempts were made to sample tray populations immediately before and after mortality periods. High prevalences were observed preceding mortality peaks, but new cases continued to appear, and often also resulted in high levels of infection after seasonal mortalities. Period of infectivity and rate of development of infections must be considered in interpreting prevalence data. All of the 12 lots of oysters exhibited high prevalences except the 1961 imports (Fig. 3) at VIMS pier. In terms of mortality, a full epizootic of MSX was assured if prevalence reached $30 \%$ in live oysters any time during the first 2 years of exposure. Hundreds of samples from planted beds which had heavy losses showed levels of MSX infection similar to those found in trays.

A complete analysis of disease prevalence in gapers for the populations in trays Y14 and Y15 at Tillage's ground is given in Table I. Dermocystidium was essentially absent from these oysters until October 1963 at the end of the experiment. During the first 2 years, 34 gapers from tray Y14 
TABLE I. Seasonal prevalence of MSX in gapers from Tillage station trays

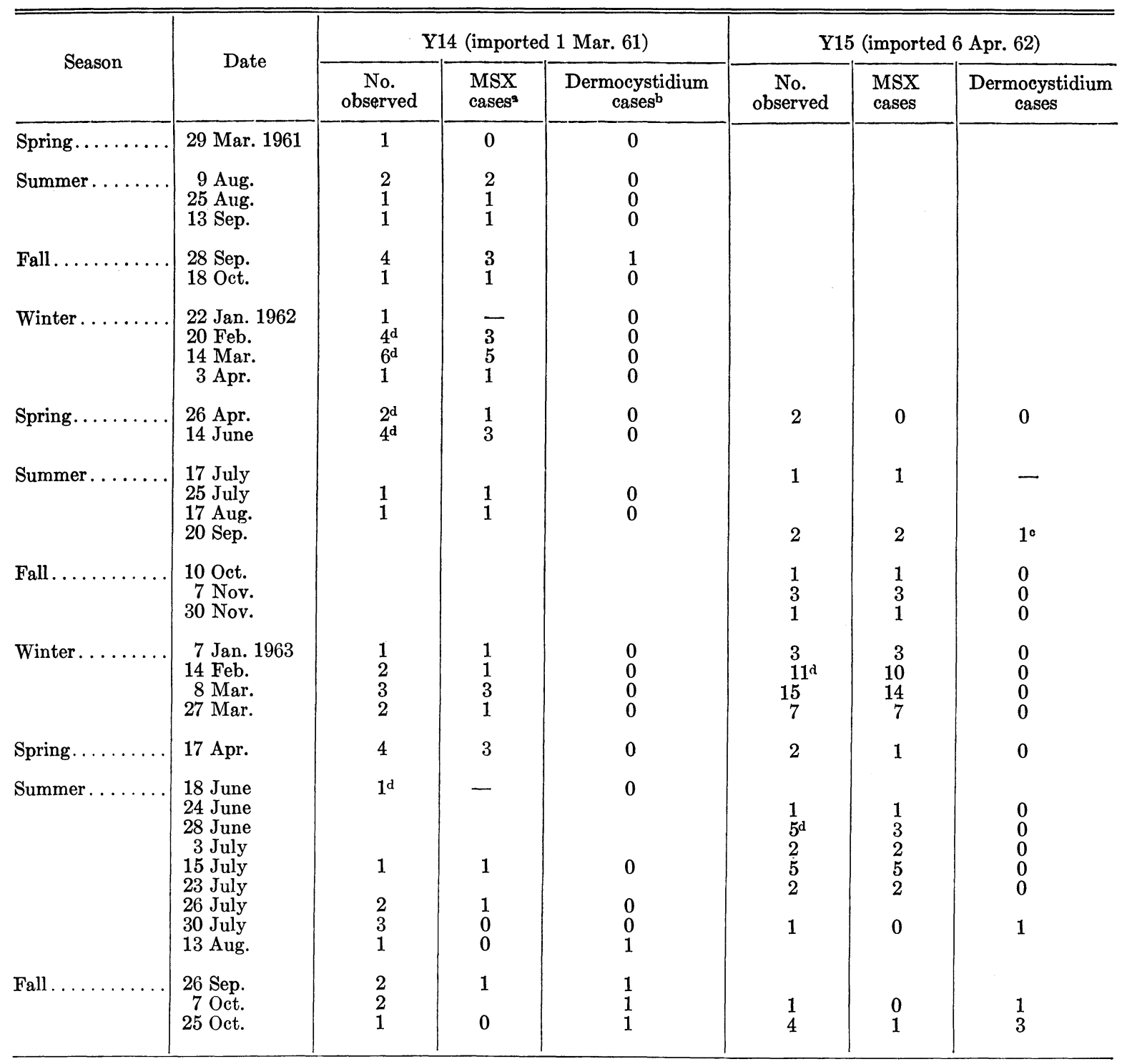

aDiagnosed by stained slides

bDiagnosed by thioglycollate culture technique

cMixed infection

dOne rotten, no diagnosis possible

were examined for diseases, excluding 4 too rotten for diagnosis. Twenty-nine had MSX infections, one had Dermocystidium, and four were sick without known cause. In the third year, only 6 cases of MSX were found in 16 gapers; 4 gapers had Dermocystidium and several were without apparent sickness. Tray Y15 yielded 47 gapers in one year which had 43 cases of MSX and 4 gapers not diagnosed. One oyster had a mixed infection of MSX and Dermocystidium. By November of the second year, a total of 69 gapers had 57 cases of MSX and 6 of Dermocystidium. After oyster beds were decimated by MSX in lower Chesa- peake Bay, the fungus disease became scarce. Tillage's ground was chosen to illustrate the patterns of activity of MSX because the fungus was nearly absent from 1961 to 1963 . However, the fungus slowly developed an epizootic in trays Y14 and Y15 and by the fall of 1963 had become an important cause of death (Table I). In Figure 2 the sudden rise in the mortality curves in October 1963 was caused by Dermocystidium deaths in a warm fall.

The gapers examined from trays Y14 and Y15 represent only $13 \%$ of total deaths, yet MSX was the probable cause of most deaths in these popula- 
TABLE II. Summary of MSX prevalence in gapers from Trays Y14 and Y15 at Tillages ground

\begin{tabular}{c|c|c|c|c}
\hline \hline Season & $\begin{array}{c}\text { No. } \\
\text { observed }\end{array}$ & $\begin{array}{c}\text { No. } \\
\text { MSX cases }\end{array}$ & $\begin{array}{c}\text { No. } \\
\text { Dermocystidium } \\
\text { cases }\end{array}$ & Rotten \\
\hline First spring..... & 3 & 0 & 0 & 0 \\
Summer....... & 33 & 24 & 3 & 2 \\
Fall........... & 20 & 11 & 8 & 0 \\
Winter........ & 56 & 49 & 0 & 3 \\
Later springs.... & 12 & 8 & 0 & 2 \\
\hline Total........ & 124 & 92 & 11 & 7 \\
\hline
\end{tabular}

tions. Seventy-nine per cent of 117 gapers, excluding rotten ones, had MSX (Table II). Only about $9 \%$ were found with other recognizable diseases, mostly cases of Dermocystidium. Nine of the 11 cases of fungus disease occurred at the end of the study in the fall of 1963 and 3 were not of killing intensity.

In Table III the prevalence of Dermocystidium in gapers is shown for the VIMS trays of oysters presented in Figure 3 . The fungus caused only about $10 \%$ of deaths in late-summer imports but about two-thirds in spring of 1960 imports. Losses from the fungus were concentrated in September and October.

The mortalities described for Mobjack Bay in 1963 in Figure 4 were almost entirely caused by MSX. A high percentage of gapers had cases of MSX and infections in gapers occurred with similar frequency at all seasons of the year. An exception was the old oysters in tray MJ2 which yielded a number of gapers without MSX infections. No Dermocystidium was found in live oysters or gapers from trays or planted beds in Mobjack Bay in 1963.

\section{Patterns of mortality associated with MSX}

Time of importation from disease-free areas proved to be important in subsequent timing of infectivity and deaths. In Virginia, most seed stocks are moved from low-salinity public grounds to private beds from October to the following May inclusive, hence would be classed as winter-spring imports.

Oysters imported to epizootic areas in winter and spring exhibited late summer and fall deaths in the first year of exposure to MSX (Fig. 2). A reduction in death rates during early winter was followed by an increase in late winter. Mortalities were low during spring, but continued at a high level throughout the second summer. Death rates declined earlier in the second fall, and the cycle was repeated at lower levels of prevalence and mortality each succeeding year.

Oysters imported after mid-summer and before November did not begin dying until June of the following summer (Fig. 3). Losses continued throughout the summer and fall at high levels. Thereafter, late summer and fall imports followed the mortality patterns described for winter and spring imports.

\section{Death rates in winter-spring imports}

Seasons and rates of mortality in winter-spring imports are illustrated for trays at Tillage's ground for 1961 to 1963 (Fig. 2). Each year deaths from MSX began in August for oysters in their first summer of exposure. Death rates reached a peak of about $15 \%$ per month in late September followed by a slow decline as cold weather prevailed. An increase in death rates occurred in late winter during the months of February and March while oysters were still dormant. After oysters began feeding again in April and May little mortality was observed until early-summer losses in June and July of the second summer. Deaths continued in late summer and fall of the second year but at lower rates than those observed the first year. In third and fourth years after import, death rates became progressively lower for all seasons. The highest death rates occurred in the second summer with peaks, usually in late July, of 15 to $20 \%$ per month. A clear comparison of first and second years of exposure as to timing and rates of mortality can be seen in 1962 curves. Losses extended well into fall in the first year whereas a large proportion of deaths in the second year occurred in the early summer.

For purposes of explaining periods of infectivity, the June to July losses are referred to as early-summer deaths in contrast to late summer deaths from August through October. In the second and subsequent years, early-and late-summer death curves tend to be confluent and are not

TABLE III. Prevalence of Dermocystidium in 1961 in trays of oysters illustrated in Figure 3

\begin{tabular}{|c|c|c|c|c|c|c|c|}
\hline Tray No. & No. dead ${ }^{a}$ & $\begin{array}{l}\text { Gapers } \\
\text { tested }\end{array}$ & \multicolumn{4}{|c|}{$\begin{array}{c}\text { No. Dermocystidium } \\
\text { infections, by } \\
\text { intensityb }^{\mathrm{b}}\end{array}$} & $\begin{array}{l}\text { Probably killed } \\
\text { by Dermocystidium } \\
\text { (\% of dead) }\end{array}$ \\
\hline & & & $\mathrm{H}$ & $\mathrm{M}$ & $\mathrm{L}$ & $\mathrm{N}$ & \\
\hline 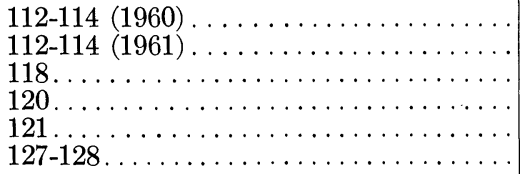 & $\begin{array}{r}423 \\
282 \\
123 \\
130 \\
142 \\
96\end{array}$ & $\begin{array}{l}80 \\
88 \\
37 \\
33 \\
49 \\
33\end{array}$ & $\begin{array}{r}48 \\
38 \\
0 \\
2 \\
4 \\
5\end{array}$ & $\begin{array}{r}9 \\
19 \\
4 \\
1 \\
2 \\
2\end{array}$ & $\begin{array}{r}11 \\
1 \quad 4 \\
2 \\
0 \\
2 \\
3\end{array}$ & $\begin{array}{l}12 \\
27 \\
31 \\
30 \\
41 \\
23\end{array}$ & $\begin{array}{r}71 \\
65 \\
11 \\
9 \\
12 \\
21\end{array}$ \\
\hline
\end{tabular}

a July to December inclusive; other months were excluded because Dermocystidium rarely kills oysters outside this period.

bHeavy, moderate, light and negative categories defined by Andrews and Hewatt (1957). Only heavy and moderate infections are associated with oyster deaths. 


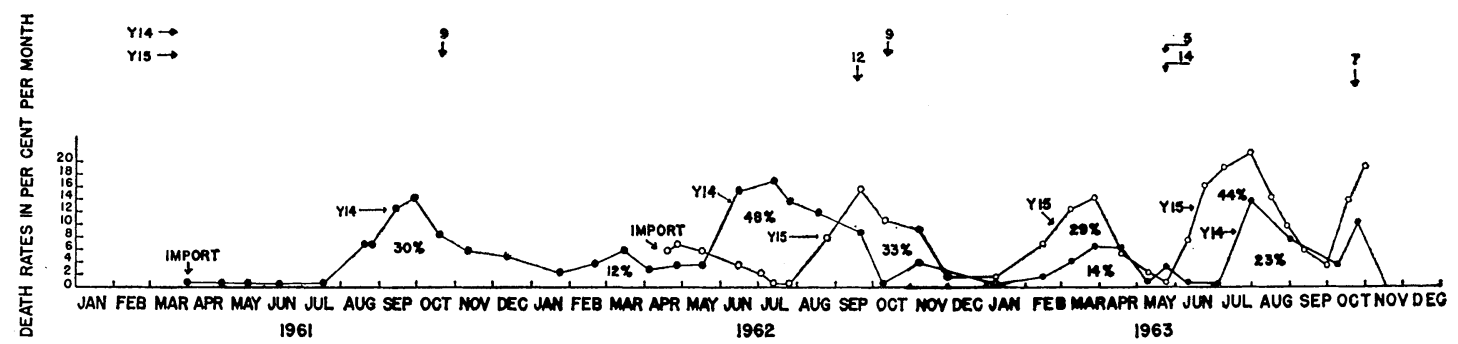

FIG. 2. Death rates of spring-imported oysters in trays at Tillage's ground in York River. Y-14 imported 1 March 1961 and Y-15 on 6 April 1962. Mortality for each seasonal peak is given under the curve. These cannot be added directly to obtain cumulative mortality. Number of MSX infections per 25 live oysters is shown above arrows which indicate date of sampling.

easily separated even though the respective infections originate in different calendar years.

Total losses for each seasonal mortality are shown under the curves in Figure 2. For each import about onethird of the oysters died the first late summer and fall. Late-winter losses varied from 12 to $29 \%$ and were heavier in 1963 than in 1962 in both first- and second-winter lots. Unreported data indicate that second-winter losses were usually less than those in the first winter, but evidently environmental stress was great in 1963. After further losses of 44 to $48 \%$ had occurred in the second summer, tray populations were seriously depleted in numbers.

Accumulative mortalities at various intervals after import indicate the problem besetting oyster planters in lower Chesapeake Bay. Y14 had 30\% losses by November of the first year. At the end of the first year in April 1962, 42\% had died. By the second November, 71\% had been lost and at the end of the second year in April $1963,74 \%$ of the oysters had died. Y15 had 33\% loss the first summer, 52 the first year and 75 by November of the second year. These figures are not explicitly given in tables or figures but can be calculated from them.

Patterns of mortality in late-summer and fall imports

Death rates for five of numerous imports to VIMS pier at Gloucester Point are given in Figure 3. Three late-

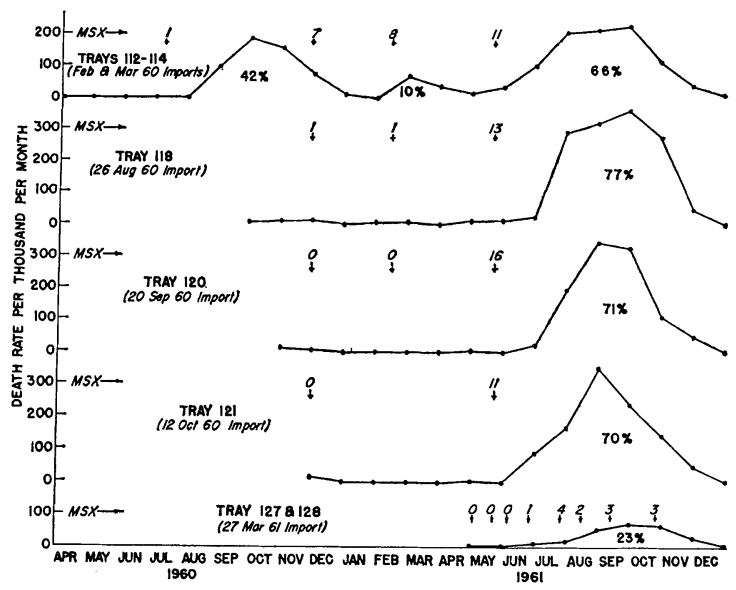

FIG. 3. Death rates and incidences of MSX in live oysters for spring and fall imports in trays at VIMS pier. Three trays of late-summer and fall-of-1960 imports are shown between trays of spring imports of 1960 and 1961. Number of MSX infections per 25 live oysters is shown above arrows indicating sampling dates. Dermocystidium was involved in August and September losses. summer imports are arranged chronologically between spring imports for 1960 and 1961 shown at the top and bottom of the graph for comparison. These August, September and October imports did not begin to die until early summer of the following year. Deaths continued at high rates throughout summer and fall of the second year. Thereafter, patterns and rates of mortality were similar to those described for winter-spring imports. All of the seasonal mortality periods in Figure 3 were initiated by MSX-caused deaths, but, beginning in August each year, Dermocystidium also caused deaths. The patterns of mortality can be ascribed to MSX, but rates in late

\section{MOBJACK BAY TRAYS}

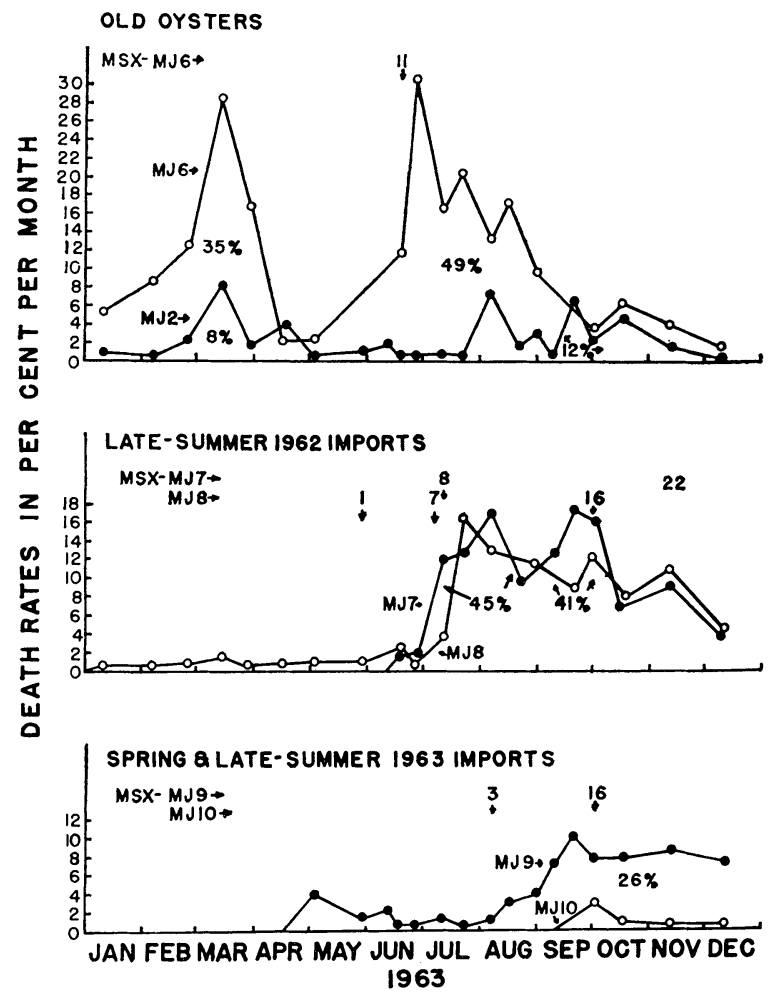

Fig. 4. Death rates of various ages of tray oysters in Mobjack Bay in 1963. Groups arranged from top in order of length of exposure in MSX-infested area. Note difference in timing of deaths in late-summer-1962 and spring-1963 imports. No early-summer mortality occurred in spring imports. 
summer were accelerated by the fungus. The proportion of deaths caused by Dermocystidium will be given later. Another complication is that MSX activity declined at Gloucester Point in 1961 and 1962 as indicated by the spring of 1961 imports. It is clear, however, that oysters imported as early as late August 1960 did not die from MSX until July of the following summer. This is an extensive time delay in comparison to the quick deaths from early-summer imports. No winter mortality occurred in late-summer imports the first year.

Death rates in a series of imports to Mobjack Bay are shown in Figure 4. These groups were free of Dermocystidium; hence Figure 4 depicts deaths caused mostly by MSX. The middle pair of curves representing latesummer imports of 1962 clearly show the long delay before deaths began in July of the following year. The population in MJ7 was imported 18 September 1962 and held in a tray. The tray was lost from January to June 1963 during which time only 2 of 495 oysters died. Tray MJ8 contained oysters planted on private beds in Mobjack in August 1962 and harvested in January 1963. Oysters left by dredgers were then placed in a tray for study. Both groups were disease-free lots imported from James River. A comparison with spring imports of 1963 (MJ9) shows differences in timing of peaks and rates of mortality. In MJ9 the late-summer mortality very closely matches the one in MJ7, but early summer losses did not occur. The losses in MJ9 prior to 1 August were characteristic of all James River oysters in 1963 but the causes are uncertain and MSX was not involved.

The old oysters represented in the top pair of curves (Fig. 4) included groups in their second (MJ6) and fifth (MJ2) years of exposure to MSX. Although mortalities remained high in the second year group, they were much reduced by the fifth year. Both groups were reduced to about 100 oysters at the end of 1963 which explains partly the irregularity of the death curves. An increasing proportion of deaths in MJ2 (about one-third in 1963) were from pathological agents other than MSX.

\section{Patterns of mortality in Mobjack Bay}

Mobjack Bay was an early center of activity for MSX in Chesapeake Bay. Heavy losses were experienced on planted beds beginning in the summer of 1959 . No natural populations occur in this area and only trial plantings have been made since the spring of 1960 . After the survivors had been dredged, few oysters remained in this area. In 1964 a dredge boat caught only 10 to 15 bushels of live oysters per day. Yet, without new plantings, MSX has persisted with high intensity of activity in Mobjack Bay whereas Dermocystidium has nearly disappeared.

Death rates and seasonal losses in Mobjack Bay can be attributed almost entirely to MSX insofar as our present knowledge of diseases is concerned. A high pro- portion of gapers from trays had MSX infections and prevalence in live oysters was similar to that found on planted beds.

One commercial bed of James River seed has been planted in Mobjack Bay each year for trial purposes. The tray station was located on the edge of these plantings. New trays of susceptible oysters were added each year. The date of import for each tray is indicated by the beginning of the mortality curve, except for MJ2 which was imported by commercial oystermen in 1958 .

Death rates for new imports and acclimated oysters in Mobjack Bay are shown for 3 consecutive years in Figure 5. In new imports, deaths began in August the first year and in June the second year thus clearly repeating the patterns previously described. Acclimated oysters, which had been exposed one or more summers to MSX activity, always showed early-summer losses as well as late-summer and late-winter mortalities. In the absence of Dermocystidium, a separation of MSX kills into early-summer and late-summer peaks is suggested in the curves. The early-summer kill with its peak in late July appears to be larger than the late-summer mortality. The timing and level of kill by MSX in Mobjack Bay were repeated each year with remarkable similarity of pattern to that observed in other areas.

\section{Summary of mortality data}

A summary of tray mortalities at all stations for winter- and spring-imported oysters in fully epizootic areas is given in Table IV. Enough gapers were obtained from each tray to confirm that oysters were dying with MSX infections and to give some indication of Dermocystidium activity. Live oyster samples were taken from the trays in late summer or fall at the peak of fungus activity as a further check on disease incidence.

To indicate the level of Dermocystidium activity, the percentage of gapers with serious infections (heavy and moderate cases) is given. Caution must be used in applying these percentages to determine specific mortality rates. The number of gapers recovered per tray varied from 4 to 49 with uneven distribution throughout the year. Oysters with patent infections of both MSX and Dermocystidium were infrequent, yet death rates caused by Dermocystidium were apparently accelerated in MSX-infested areas. Then as oyster populations on planted beds became depleted the fungus disappeared. Note that Dermocystidium was never

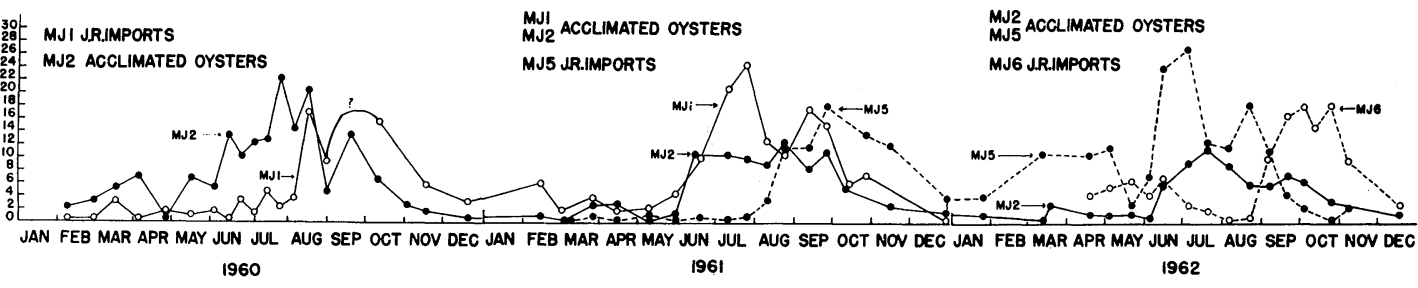

FIG. 5. Death rate curves for tray-grown oysters in Mobjack Bay. Date of import is indicated by beginning of curve except for Tray MJ2. Each year spring imports from James River began dying in August whereas acclimated oysters began dying earlier in the summer. 
TABLE IV. Summary of mortalities for winter- and spring-imported oysters in MSX-infested areas. Dermocystidium activity indicates percentage of gapers with heavy and moderate infections

\begin{tabular}{|c|c|c|c|c|c|c|c|c|c|c|c|}
\hline \multirow[b]{3}{*}{ Date of import } & \multirow[b]{3}{*}{ Group } & \multirow{3}{*}{ Location 1} & \multirow{2}{*}{\multicolumn{2}{|c|}{ Dermocystidium (\%) }} & \multicolumn{6}{|c|}{ Mortality (\%) } & \multirow{3}{*}{$\begin{array}{l}\text { Third } \\
\text { Summer }\end{array}$} \\
\hline & & & & & \multicolumn{3}{|c|}{ First year } & \multicolumn{3}{|c|}{ Second year } & \\
\hline & & & First year & Second year & Summer & Winter ${ }^{b}$ & Year $^{\circ}$ & Summerd & Winter & Year & \\
\hline \multicolumn{12}{|l|}{1959} \\
\hline $11 \mathrm{Mar} . . \ldots \ldots \ldots \ldots \ldots$ & $\mathrm{Y}-6$ & Amoco & 88 & - & 40 & - & - & - & - & - & - \\
\hline $11 \mathrm{Mar} . \ldots \ldots \ldots \ldots \ldots$ & Y-7 & Amoco & 88 & - & 44 & - & - & - & - & - & - \\
\hline $14 \operatorname{Mar} . \ldots \ldots \ldots \ldots \ldots \ldots$ & $\mathrm{Y}-3$ & Tillage's & 40 & 33 & 19 & 12 & 30 & - & - & - & - \\
\hline 21 May..... & $\mathrm{J}-4$ & Hampton Bar & 80 & 38 & 33 & 6 & 38 & 64 & - & - & - \\
\hline 21 May. $\ldots \ldots \ldots \ldots \ldots \ldots$ & J-5 & Hampton Bar & 46 & 62 & 25 & 5 & 29 & 59 & 17 & 65 & 50 \\
\hline 25 Nov. $\ldots \ldots \ldots \ldots \ldots$ & $Y-9$ & Amoco & 63 & 7 & 55 & - & - & - & - & - & - \\
\hline 25 Nov................ & MJ-1 & Mobjack & 0 & 20 & 33 & 19 & 46 & 55 & - & - & - \\
\hline \multicolumn{12}{|l|}{1960} \\
\hline 23 Feb..$\ldots \ldots \ldots \ldots \ldots$ & Y-10 & Tillage's & 26 & 20 & 40 & 28 & 57 & 52 & 3 & 55 & - \\
\hline 23 Feb................. & Y-11 & Amoco & 47 & 0 & 49 & 20 & 60 & - & - & - & - \\
\hline \multicolumn{12}{|l|}{1961} \\
\hline 1 Mar..... & Y-14 & Tillage's & 8 & 11 & 30 & 17 & 42 & 50 & 9 & 55 & 23 \\
\hline $2 \operatorname{Mar} . \ldots \ldots \ldots \ldots \ldots \ldots$ & MJ-5 & Mobjack & 0 & 0 & 35 & 36 & 58 & 55 & - & - & - \\
\hline $9 \operatorname{Mar} . . . \ldots \ldots \ldots \ldots$ & J-7 & Hampton Bar & 0 & - & 58 & - & - & - & - & - & - \\
\hline \multicolumn{12}{|l|}{1962} \\
\hline 19 Mar...... & MJ-6 & Mobjack & 0 & 0 & 42 & 43 & 67 & 51 & - & - & - \\
\hline $6 \mathrm{Apr}, \ldots \ldots \ldots \ldots \ldots$ & Y-15 & Tillage's & 20 & 2 & 32 & 29 & 51 & 50 & 9 & 55 & - \\
\hline \multicolumn{12}{|l|}{1963} \\
\hline 5 Mar........ & $\mathrm{Y}-16$ & Amoco & 0 & - & 26 & 19 & 40 & - & - & - & - \\
\hline 9 Apr $\ldots \ldots \ldots \ldots \ldots$ & Y-17 & Tillage's & 0 & - & 29 & 13 & 38 & - & - & - & - \\
\hline 16 Apr................ & MJ-9 & Mobjack & 0 & - & 25 & 25 & 44 & - & - & - & - \\
\hline
\end{tabular}

aFrom date of import to 1 November excluding occasional spring transplanting losses. bFrom 1 November to 1 April. Losses were primarily in late winter. -From date of import to 31 March of following year.

dFrom 1 April of second year to 1 November.

very abundant in Mobjack Bay. At VIMS pier where trays of susceptible oysters were imported regularly, the fungus persisted abundantly through 1963 ; for this reason most data from numerous VIMS pier trays have been omitted.

Mortality figures by periods (Table IV) indicate that first-summer losses were typically onethird or more and first-year losses usually totaled 50 to $60 \%$. Winter losses were quite variable and usually were higher the first winter than the second. Second-summer losses usually exceeded $50 \%$ but second-year mortalities were not much above firstyear losses. Losses were as great in 1962 and 1963 imports when Dermocystidium was nearly absent as in 1959 and 1960 imports when it was very active. Yet MSX activity was rather steady as indicated by the fungus-free Mobjack Bay trays (Fig. 5).

Cumulative mortalities for various periods of exposure during the MSX epizootic are given in Table V. Any period up to 13 months represents at most only one summer and one winter period of mortality. Again Dermocystidium was an important cause of deaths in 1959. Since 2 consecutive years of losses at the rate of $50 \%$ per year add up to only $75 \%$ cumulative mortality, it is not
TABle V. Accumulative mortalities of winter- and springimported oysters in highly epizootic areas. Period of observation determined from date of import from diseasefree area

\begin{tabular}{|c|c|c|c|c|}
\hline $\begin{array}{l}\text { Period of } \\
\text { observation } \\
\text { (months) }\end{array}$ & $\begin{array}{l}\text { Month and } \\
\text { year of } \\
\text { import }\end{array}$ & Group & Location & $\begin{array}{c}\text { Mortality } \\
(\%)\end{array}$ \\
\hline $4 \ldots \ldots \ldots \ldots \ldots \ldots$ & Mar. 1964 & Y19 & Tillage's & 1 \\
\hline $7 \ldots \ldots \ldots \ldots \ldots \ldots$ & Mar. 1959 & $\mathrm{Y} 6$ & AMOCO & 40 \\
\hline $7 \ldots \ldots \ldots \ldots$ & Mar. 1959 & $\mathrm{Y} 7$ & AMOCO & 44 \\
\hline $8 \ldots \ldots \ldots \ldots$ & Mar. 1961 & J7 & Hampton Bar & 58 \\
\hline $12 \ldots \ldots \ldots \ldots \ldots \ldots$ & Mar. 1959 & Y3 & Tillage's & 30 \\
\hline $13 \ldots \ldots \ldots \ldots \ldots \ldots$ & Nov. 1959 & Y9 & $\mathrm{AMOCO}$ & 55 \\
\hline $13 \ldots \ldots \ldots \ldots$ & Feb. 1960 & Y11 & $\mathrm{AMOCO}$ & 60 \\
\hline $15 \ldots \ldots \ldots \ldots \ldots \ldots$ & Apr. 1963 & MJ9 & Mobjack Bay & 62 \\
\hline $15 \ldots \ldots \ldots \ldots \ldots \ldots$ & Apr. 1963 & Y17 & Tillage's & 55 \\
\hline $16 \ldots \ldots \ldots \ldots \ldots \ldots$ & Mar. 1963 & Y16 & AMOCO & 59 \\
\hline $17 \ldots \ldots \ldots \ldots$ & May 1959 & $\mathrm{~J} 4$ & Hampton Bar & 78 \\
\hline $17 \ldots \ldots \ldots \ldots$ & Mar. 1960 & $\mathrm{~J} 6$ & Hampton Bar & 78 \\
\hline $19 \ldots \ldots \ldots \ldots$ & Mar. 1961 & MJ5 & Mobjack Bay & 81 \\
\hline $19 \ldots \ldots \ldots \ldots \ldots \ldots$ & Mar. 1962 & MJ6 & Mobjack Bay & 70 \\
\hline $23 \ldots \ldots \ldots \ldots \ldots$ & Nov. 1959 & MJ1 & Mobjack Bay & 70 \\
\hline $25 \ldots \ldots \ldots \ldots$ & Feb. 1960 & Y10 & Tillage's & 81 \\
\hline $26 \ldots \ldots \ldots \ldots$ & Apr. 1962 & $\mathrm{Y} 15$ & Tillage's & 80 \\
\hline $27 \ldots \ldots \ldots \ldots$ & May 1959 & J5 & Hampton Bar & 88 \\
\hline $32 \ldots \ldots \ldots \ldots \ldots \ldots$ & Mar. 1961 & Y14 & Tillage's & 80 \\
\hline
\end{tabular}

surprising that few groups of oysters reached a total loss of $80 \%$. Cumulative mortality rises very slowly after 2 years even with high death rates. Seasonal and annual rates are much more informative. 
Annual cycle of $M S X$ epizootic

\section{Seasonal prevalence of $M S X$}

Rate of occurrence of new infections is difficult to obtain for MSX because throughout the warm season new infections are appearing and deaths are occurring simultaneously. Over 200 samples of live oysters from populations in epizootic areas have been examined for incidence of MSX. But these relate to numerous tray and bed populations with various histories over a 5-year period. In addition, a sample size of 25 permits rather wide confidence limits. Hence, no attempt has been made to average prevalence data. Rather, trends have been interpreted from sequential samples. A few populations have been sampled intensively around the year, but these data have not proven entirely satisfactory for various reasons.

Sequential data on infections in three populations of oysters are given in Figure 6. Plot 14-16 in Mobjack Bay is a private bed which was planted with seed from lower James River in late August 1961. A sampling program on adjacent beds in James River indicated that these seed oysters had hidden or suppressed infections when transplanted; MSX infections appeared on these beds later in the fall. Infections initiated in August in Mobjack Bay would not have appeared until May of the following year. By mid-September when the first sample of the transplants was taken, an incidence of $12 \%$ was found. For study of seasonal prevalence of MSX, this population is comparable to winter-spring imports except for delayed appearance of MSX and reduced late-summer mortality. A fall and winter prevalence of 30 to $50 \%$ was followed by a late-winter mortality of about 12 to $15 \%$, but reduction in incidence is not clearly defined. A sharp rise in incidence in April and May preceded early-summer mortality which reduced incidence to about 20\%. Then another rise in incidence occurred in late summer.

The population of oysters in tray 127 was imported in April 1961 to monitor MSX prevalence at VIMS pier at Gloucester Point. Certain localities and beds within the epizootic area failed to maintain consistently high levels of MSX in 1961 and 1962 for inexplicable reasons. Unfortunately, our Gloucester Point test station was one of these areas in which incidence was low, and seasonal patterns of infection are illustrated poorly by tray 127. The third group in Figure 6 was a private planting in Mobjack Bay on Cuthbert and Hughes' ground. These oysters were planted in the spring of 1959 and after a late-summer and fall mortality showed a high prevalence in May 1960 from infections initiated the previous late summer.

Data on infection level in this section relate mostly to winter-spring imports. Prevalence of MSX in fall imports was presented in Figure 3. After the first full summer of exposure, oysters were infected and killed at slightly lower levels each year in the typical patterns described for spring imports. After the second summer of exposure to MSX, when some $70 \%$ of the original population had died, prevalence usually tended to remain at lower levels (15 to $25 \%$ ) with less seasonal fluctuation. Much of the interpretation of seasonal patterns of MSX prevalence was obtained from the irregular samples of live oysters from trays, data for some of which are given with mortality curves (Fig. 2 to 5 ).

\section{Relation of infections to mortalities}

The relation of seasonal prevalence to mortality patterns is given in Figures 7 and 8, which should be studied together. Spring imports to Mobjack

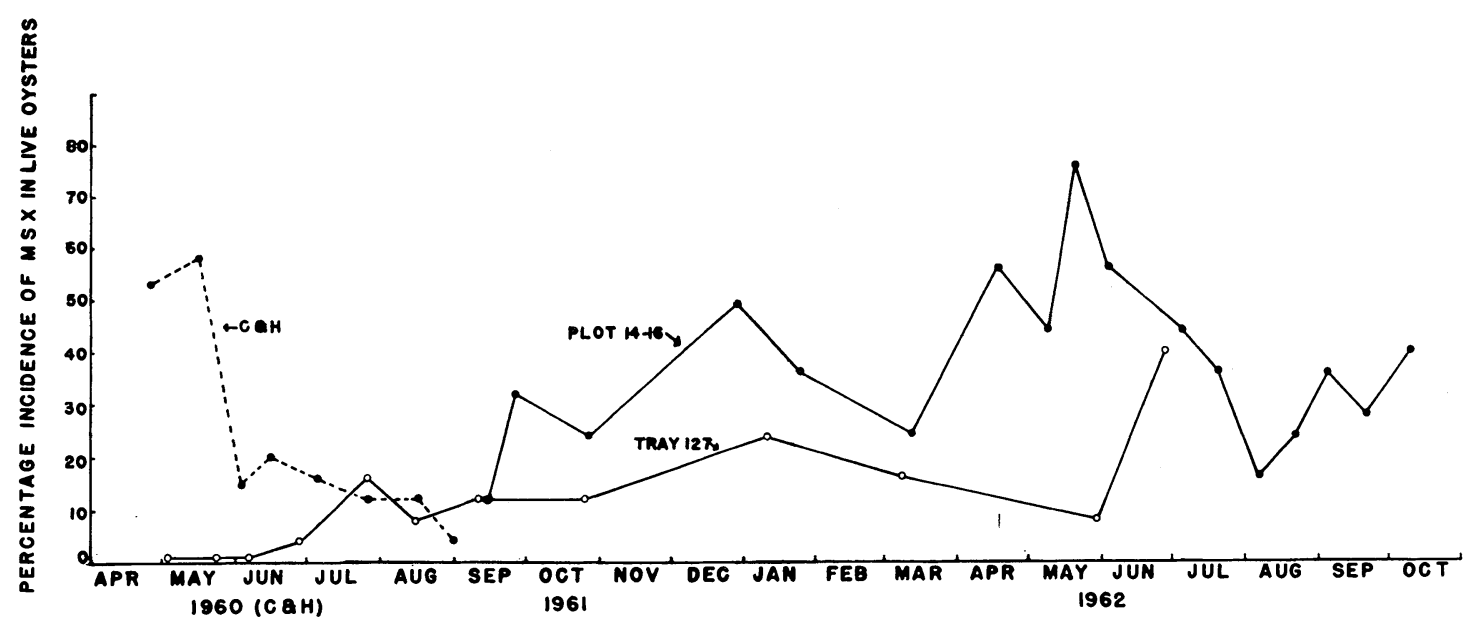

FIG. 6. Incidence of MSX in three populations of spring-imported live oysters. Cuthbert and Hughes', and plot 14-16 oysters were from planted beds in Mobjack Bay where MSX activity was intense. Tray 127 at VIMS pier exhibited low prevalence in 1961 and is not typical of fully epizootic areas. 


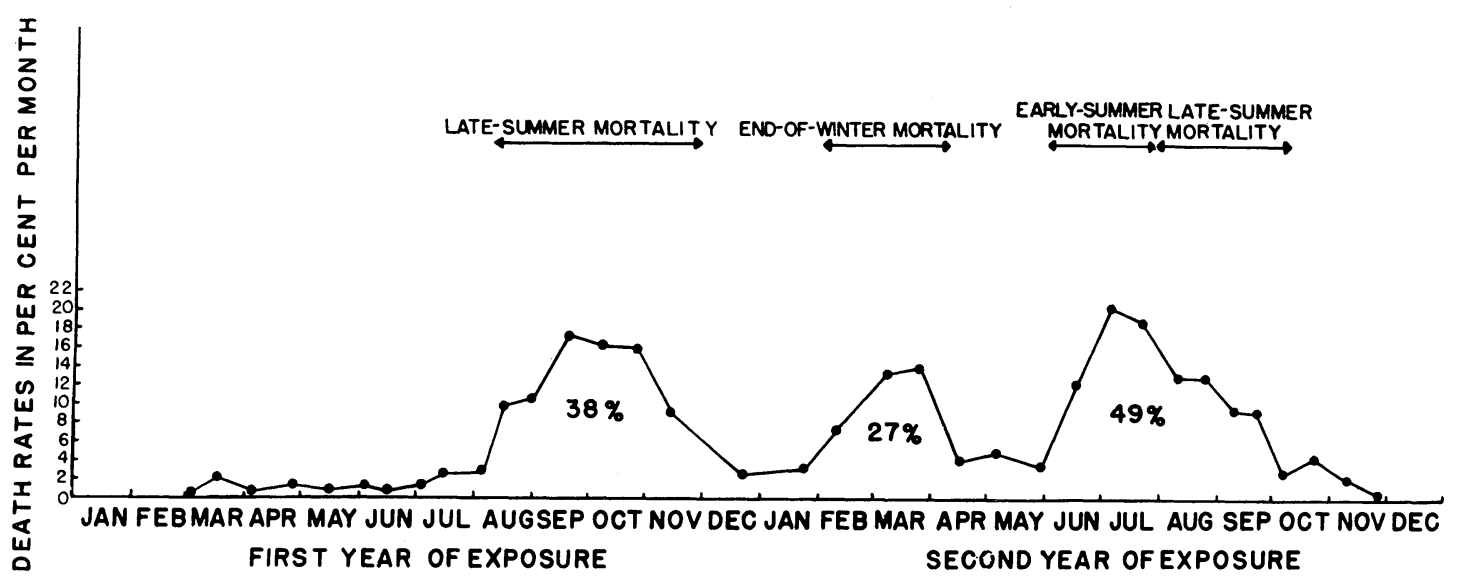

FIG. 7. Average death rates for three trays of spring-imported oysters in Mobjack Bay. These death rates represent the averages for trays MJ5, MJ6 and MJ9 imported about 1 April in 1961, 1962 and 1963 respectively. Most deaths were caused by MSX and Dermocystidium was absent.

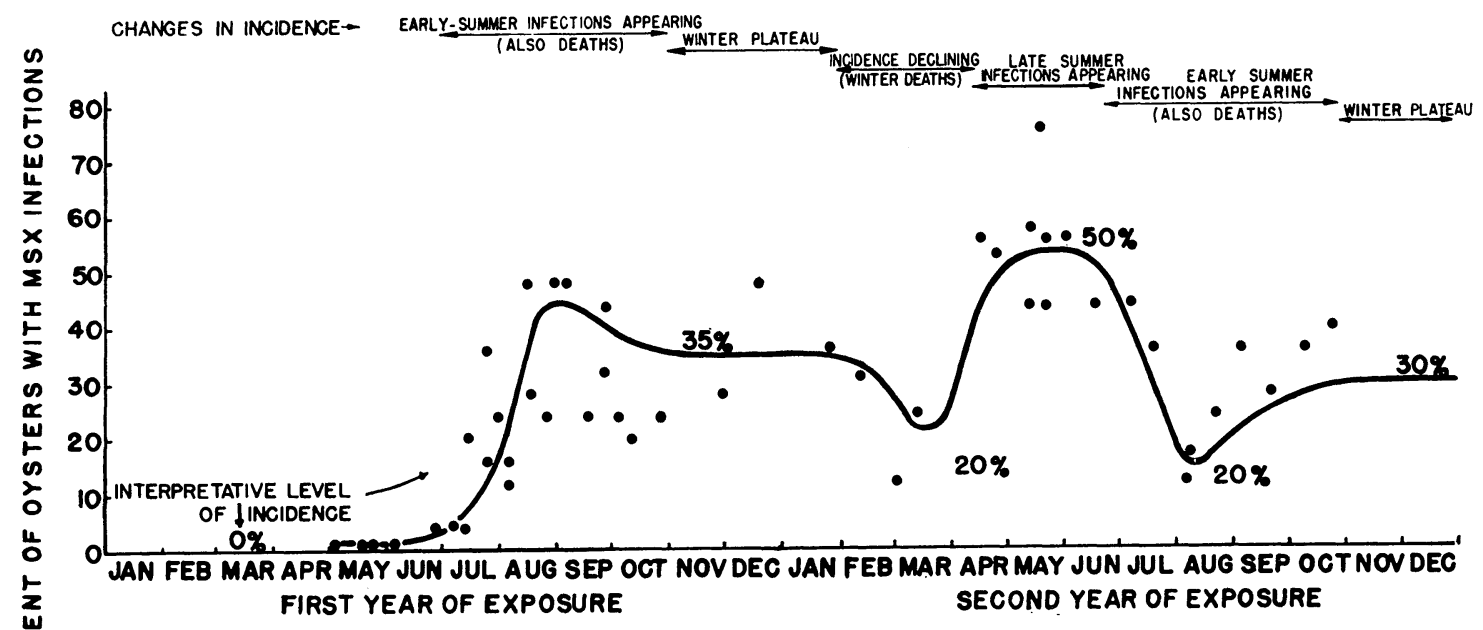

Fig. 8. Seasonal prevalence of MSX in fully epizootic areas. Plotted points represent incidence in samples of 25 oysters from various populations over a 5-year period. A diagrammatic curve depicts the author's interpretation of the pattern of infection for the first 2 years after import. The duration of periods of MSX activity and the causes of changes in incidence are shown at the top of the graph.

Bay for the years 1960, 1961 and 1962 were matched as to examination dates and the death rates averaged for the first 2 years of exposure (Fig. 7). The regularity of MSX mortality is convincingly demonstrated by the repetition in 3 -year averages of seasonal patterns of kill previously described.

Prevalence data, for populations with the same history of exposure to MSX as the Mobjack trays in Figure 7 are presented in Figure 8. Percentage of infection is plotted for all samples from winter and spring imports in fully epizootic areas. Data from 5 years of sampling in several localities of two rivers are presented. Each point in Figure 8 represents a sample of 25 live oysters.
A free-hand curve has been drawn to depict prevalence patterns for about 2 years from time of importation. The curve represents the author's interpretation of levels of infection as deduced from all data in all years and does not necessarily follow the plotted points. The second-winter plateau of incidence was lower in most years than the plotted points indicate. For convenience of the reader, the author has indicated the approximate percentages of infection usually observed at various periods after import. Variations in timing of infections and deaths among so many populations over several years tended to obscure peaks and lows in the composite of plotted points. Salinities and temperatures, among other probable factors, 
are known to influence timing of appearance of infections and deaths hence they alter incidence from year to year and place to place. Nevertheless, a definite pattern of incidence from time of import prevails.

\section{Conclusions and Discussion}

\section{Seasonality of infections and mortalities}

It is concluded from prevalence and mortality data on numerous imports that oysters in natural waters became infected with MSX from late May until about November each year. These infections can be classified into two groups according to the timing of appearance of plasmodia and subsequent deaths. Early-summer infections, occurring chiefly in June and early July, develop plasmodia in 5 to 16 weeks and cause deaths beginning in August for a late-summer and fall mortality. In some oysters, early-summer infections develop slowly and do not become lethal by the time winter temperatures prevail. This results in a low death rate in winter and spring, except for an end-of-winter kill and another final peak in June of the second summer. Late-summer infections, beginning in July and continuing through October, cause oysters to stop growing but remain hidden or localized and do not appear as recognizable cases until about May of the following year. These infections result in early-summer kills (June and July) with some straggling deaths in late summer. In summary, infections are acquired during the period of high mortality from June to October but there is no evidence that infections are initiated from November to May.

Prevalence for a particular season is easily modified by environmental and population factors. For example, MSX infections develop slowly in lowsalinity areas such as James River seed area (Andrews 1964). Infections acquired there in early summer do not appear until October and no late-summer mortality occurs. Thus, no infections are detectable through the summer and a relatively high prevalence is found through the winter because few have died. Hence, low-salinity areas present a distinctive picture of seasonal prevalence of MSX. Even in fully epizootic areas, shifts in duration of incubation and timing of deaths make it difficult to average seasonal prevalences. Yet there are obviously seasonal changes in occurrence of MSX of considerable magnitude and the same pattern is followed each year.

\section{Incubation period and hidden or latent infections}

Variation in length of incubation period is one of the most puzzling and inexplicable facets of Delaware Bay disease. The shortest observed period from import to patent infection was 5 weeks. However, infections initiated in early summer may first become evident any time from July to November and possibly later. The incubation period for late-summer infections appears to be from 7 to 10 months. Numerous oysters from groups with latent infections have been sectioned and examined for disease with only occasional localized infections being found. A simple explanation would be that all late-summer infections are localized infections which cross sections in one area do not reveal. The alternative is that some unrecognized stage of MSX precedes the plasmodial stage. In any case, it is hard to understand why all late-summer infections should remain hidden and relatively localized or inactive through several months of warm weather in late summer and fall. After a long period of incubation, latesummer infections appear suddenly almost in unison in May. This contrasts sharply with the irregular appearance of early-summer infections.

\section{Temperature and MSX activity}

Seasonality of infections and deaths is important in invertebrate diseases because a change in temperature may alter the pathogenic relationship between host and parasite. Dermocystidium kills during the warm season and apparently disappears in the cold months. MSX infects and kills oysters primarily in the warm season yet infections do not appear to be lost in winter in Virginia waters. Death rates decreased as temperatures were lowered in the fall and winter but in February and March serious losses occurred again. Since no rise in temperature occurred, environmental stress from duration of low temperatures is implied. A few oysters with early-summer infections survived the winter and died in May and June of the second year. Late-summer infections apparently do not advance during the winter and no winter deaths were observed. In May, late-summer infections could be readily distinguished from older infections by intensity of MSX.

The mid-summer change in duration of the incubation period of MSX occurred at the warmest summer temperatures. This mysterious clue to the life cycle has not been explained. There is no scarcity of dying oysters in late summer to provide infective particles. No change of temperature or salinity was observed, yet the life cycle changed abruptly. These patterns of early-summer and late-summer infections are easily obscured if care is not taken to avoid importing oysters with incipient infections.

\section{Intensity of infections and level of epizootics}

Data on intensity of infections have not been analyzed for presentation in this paper. Categories 
of heavy, moderate and light have been established based on number of plasmodia per oil-objective field. Nearly all infections appeared to be systemic before death occurred. Intensive infections predominated in dying oysters, but some light cases were found. The first oysters to die in late summer in new groups of susceptible oysters were most commonly associated with low-intensity infections. Those oysters which resisted MSX until the end of winter or early summer of the second year almost invariably exhibited heavy infections upon death. Presumably variations in resistance of oysters to the disease accounted for some early deaths whereas other oysters resisted MSX for almost a full year.

Prevalence of MSX in live oysters was determined in numerous populations at all seasons of the year by sampling. During the summer, cases were being added by new infections and removed simultaneously by deaths. This made it difficult to determine the total number of cases from earlysummer infections. Since in most populations about two-thirds of the oysters died from MSX within 1 year after first infections occurred, and since this happened before oysters began dying from late-summer infections, it can be concluded that at least $60 \%$ were infected in the first earlysummer exposure period. Samples taken at times of expected high prevalence revealed typically about $35 \%$ infection but sometimes reached $65 \%$, particularly if mortality was low the first late summer and fall.

Changes in prevalence were quite small during early winter but deaths removed some cases, beginning about 1 February each year, without compensating new infections. Late-summer infections appeared almost simultaneously in May during a period of low mortality, thereby providing an opportunity to assess the total number of cases from one infection period. The level of infection frequently exceeded $50 \%$ in May samples.

High levels of MSX activity have been maintained in large areas of lower Chesapeake Bay since the MSX epizootic began in 1959. At most stations both early- and late-summer infections have never failed despite drastic declines in oyster populations from 1959 to 1963 . This suggests that infection sources are independent of oyster populations, and that direct infections from oyster to oyster may not occur. Failure to transmit MSX in the laboratory supports this concept. The consistent level of MSX prevalence from year to year also suggests outside sources of infection. Dermocystidium has attained $100 \%$ infection in a number of observed populations but MSX rarely exceeds 60 or $65 \%$. Of those which escaped infection the first year, almost as large a percentage became in- fected in the second year. This is puzzling in terms of oyster resistance and infection pressure. It almost appears that infections are acquired by chance exposure, yet all oysters in a tray are exposed to essentially the same environment.

\section{Method of transmission and origin}

A satisfactory theory of the epizootiology of Delaware Bay disease is almost impossible at present. None of Koch's postulates has been fully satisfied. By reason of a very extensive experience with the distribution of MSX and associated mortalities, it is probable that the first postulate, that of regular association, has been satisfied indirectly. This conclusion is supported by similar experiences of scientists at several Atlantic Coast laboratories. There is no clear macroscopic or microscopic syndrome by which Delaware Bay disease can be identified except by the preserce of characteristic plasmodia. The only three common and well-known oyster diseases in Virginia are all systemic with multi-nucleate plasmodia and they appear to be water-borne and essentially blood diseases. While subtle differences in the reactions of oysters to various pathogens are indicated, these have not been formulated into syndromes by which the diseases can be diagnosed without observing the pathogens.

The failure to obtain experimental infections and the absence of a spore stage of MSX in oysters have complicated the search for the method of transmission. The key to the theory of a disease as well as to its control lies in the method of transmission. The evidence strongly suggests that MSX is water-borne, and that infective particles are filtered from the water by the oyster. The filtering capacity of oysters is enormous, yet the distance that infective particles may be transported by currents and still be collected by oysters in sufficient numbers to initiate infections is problematical. Transmission in the water from any distance would undoubtedly mean that dosage of infective particles is very small. The present known oyster parasites, some with alternate hosts and others without, mostly depend upon close proximity of infected hosts for transmission, e.g. Dermocystidium and Nematopsis; yet oysters which die from Dermocystidium are almost literally sacks of spores.

The evidence on method of transmission is inconclusive. Some considerations which may indicate no alternate or co-host are: 1) general distribution of MSX in all moderately salty waters of lower Chesapeake Bay implying a rather simple method of transmission ; 2) long period of infectivity from May to November suggesting no close timing with another host; 3) variable incubation 
time with no fixed period of death or release of infective particles, hence cycle of parasite in oyster not adapted to needs of another host or oyster not needed at all ; 4) apparent lack of any new immigrant host in Chesapeake Bay; 5) evidence from 10 years of intensive oyster mortality studies that MSX is new to Chesapeake Bay in terms of patterns of mortality; (6) apparent movement of infective particles up deep salty river channels for distances of many miles, which rather obviates the need for another host; 7) knowledge that another disease, caused by Dermocystidium, persists in oysters by direct water transmission without need of overwintering spores or other hosts ; 8) apparent absence of a spore stage in oysters. These considerations based on general theories of epidemiology are merely suggestive and not conclusive.

The evidence that suggests another host includes: 1) failure to transmit MSX by a variety of laboratory experiments ; 2) apparent absence of any relation between population size of oysters and intensity of MSX epizootic; 3) a steady level of MSX activity over wide areas, which suggests a rather stable source of infective particles; 4) no apparent effect of proximity of infected oysters.

The niche that oysters occupy is so characterized by the food-collecting adaptations that a parasite in its evolution might be expected to avail itself of this avenue of infection. So few organisms can feed directly on live oysters without entering the shell that direct transmission by a vector seems unlikely unless the vector is a food organism taken into the gill chamber. Moreover, the portal of entry for MSX seems to be epithelial tissues of the food-collecting apparatus and the digestive tract including the extensive ramifications of the liver tubules. However, the most prevalent site for apparent early infections, which are characterized by localization and often restriction to the epithelium, is the base of the gill lamellae where fine particles of food are carried forward to the mouth.

If the concept of water-borne dispersion of infective particles is correct, it is unlikely that control of MSX can be expected by eliminating source of infection or breaking connections between source and host. Therefore raising herd immunity on a genetic basis seems to be the only feasible solution. Unfortunately MSX has depopulated a large portion of lower Chesapeake Bay, and in this area reproduction of oysters is unsatisfactory because predation is excessive. Consequently, development of resistant strains may be very slow in nature in Chesapeake Bay.

\section{ACKNOWLEDGMENTS}

The author gratefully acknowledges continuous advice and help from John L. Wood who was actively engaged in the early research on MSX, and who organized and supervised the Microtechnique Section which processed efficiently all the slides from which MSX diagnoses have been made. The critique of Victor Sprague of Chesapeake Biological Laboratory was particularly helpful in writing the paper.

\section{Literature Cited}

Andrews, J. D. 1963. Measurement of shell growth in oysters by weighing in water. Proc. Natl. Shellfish Assoc. 52(1961) : 1-11.

. 1964. Oyster mortality studies in Virginia. IV. MSX in James River public seed beds. Proc. Natl. Shellfish. Assoc. 53(1962) : 65-84.

- 1965. Infection experiments in nature with Dermocystidium marinum in Chesapeake Bay. Chesapeake Science 6: 60-67.

—_ and W. G. Hewatt. 1957. Oyster mortality studies in Virginia. II. The fungus disease caused by Dermocystidium marimum in oysters in Chesapeake Bay. Ecol. Monogr. 27 : 1-25.

- J. L. Wood and H. D. Hoese. 1962. Oyster mortality studies in Virginia. III. Epizootiology of a disease caused by Haplosporidium costale Wood and Andrews. J. Insect. Path. 4: 327-343.

Cottam, C. and C. E. Addy. 1947. Present eelgrass condition and problems on the Atlantic Coast of North America. Trans. N. Amer. Wildl. Conf. Twelfth, p. 387-398.

Elton, Charles S. 1958. The ecology of invasions by animals and plants. Wiley, New York. 181 p.

Needler, A. W. H. and R. R. Logie. 1947. Serious mortalities in Prince Edward Island oysters caused by a contagious disease. Trans. Roy. Soc. Canada, Series III, Sect. 5, 41: 73-89.

Pritchard, D. W. 1952. Salinity distribution and circulation in the Chesapeake Bay estuarine system. J. Mar. Res. 11: 106-123.

Ricker, W. E. 1958. Handbook of computations for biological statistics of fish populations. Bull. Fish. Res. Bd. Canada 119: 1-300.

Sindermann, C. J. and L. W. Scattergood. 1954. Diseases of fishes of the Western North Atlantic. II. Ichthyosporidium disease of the sea herring (Clupea harengus). Maine Dept. Sea and Shore Fisheries Res. Bull. 19: 1-40. 